\section{Rechtschaffen und Kales}

Helga Peter

Marburg, Deutschland

\section{Definition}

Angesichts der unsicheren Reliabilität zwischen verschiedenen Auswertern bei der Schlafstadienbestimmung hatte die
Association for the Psychophysiological Study of Sleep (APSS) 1967 eine Kommission mit dem Ziel eingesetzt, die Kriterien zu standardisieren und zu vereinheitlichen. Die Vorsitzenden A. Rechtschaffen und A. Kales veröffentlichten 1968 die Ergebnisse in einem Regelwerk, das bis 2007 Anwendung fand, als es durch das $>$ „AASM-Manual“ for the Scoring of Sleep and Associated Events abgelöst wurde.

Siehe auch $\downarrow$,Polysomnographie und Hypnogramm“. 